\title{
PENGARUH STATUS SOSIAL EKONOMI ORANG TUA DAN MOTIVASI BELAJAR TEHADAP MINAT MELANJUTKAN STUDI KE PERGURUAN TINGGI PADA KELAS XI DI SMA PUSAKA 1 JAKARTA.
}

\author{
Nike Pratiwi Suciningrum \\ nike_15@feunj.ac.id \\ Fakultas Ekonomi, Universitas Negeri Jakarta \\ Endang Sri Rahayu \\ Endang_sri_rahayu@unj.ac.id \\ Fakultas Ekonomi, Universitas Negeri Jakarta
}

\begin{abstract}
ABSTRAK
Penelitian ini bertujuan untuk mendeskripsikan status sosial ekonomi orang tua, motivasi belajar, minat melanjutkan studi ke perguruan tinggi dan menguji pengaruh status sosial ekonomi orang tua dan motivasi belajar terhadap minat melanjutkan studi ke perguruan tinggi pada siswa kelas XI di SMA Pusaka 1 Jakarta. Metode penelitian yang digunakan dalam penelitian ini adalah metode ex-post facto. Sedangkan metode analisis data menggunakan analisis jalur (path analysis). Hasil analisis jalur menunjukan bahwa: (1) pengaruh langsung antara status sosial ekonomi orang tua terhadap minat melanjutkan studi ke perguruan tinggi sebesr $22,2 \%$; (2) pengaruh langsung antara motivasi belajar terhadap minat melanjutkan studi ke perguruan tinggi sebesar $14,1 \%$, dan (3) pengaruh tidak langsung antara status sosial ekonomi orang tua terhadap minat melanjukan studi ke perguruan tinggi yang dimoderatori oleh motivasi belajar sebesar $18,1 \%$.
\end{abstract}

Kata Kunci: Status Sosial, Motivasi Belajar, Minat.

\section{PENDAHULUAN}

Kualitas sumber daya manusia dipandang sebagai salah satu faktor kunci dalam era perdagangan bebas. Hal ini menyebabkan setiap negara mengembangkan dan meningkatkan sumber daya yang dimiliki agar dapat berperan dan bersaing dikancah internasional. Semakin tinggi persaingan dan tuntutan di dunia kerja juga membutuhkan sumber daya manusia yang berkualitas dengan segala 
kompetensi yang dimiliki, mampu mengembangkan diri serta bersama-sama membangun bangsa. Untuk menghadapi persaingan ini, Indonesia pun harus terus menerus berupaya untuk meningkatkan sumber daya manusia yang dimiliki. Peningkatan kualitas sumber daya manusia ini harus dilakukan secara terencana dalam proses pembangunan. Salah satu cara untuk meningkatkan kualitas sumber daya manusia adalah melalui jalur pendidikan.

Pendidikan merupakan suatu proses menyiapkan individu untuk mampu menyesuaikan diri dengan perubahan lingkungan. Pendidikan mempunyai peran penting dalam pembangunan nasional karena pendidikan merupakan salah satu cara untuk membentuk sumberdaya manusia yang berkualitas untuk mencapai tujuan pembangunan nasional. Sehingga peningkatan mutu pendidikan harus dilakukan oleh pemerintah. Undang-undang Sistem Pendidikan Nasional No.20 Tahun 2003, Bab II, Pasal 3 menjelaskan sebagai berikut:
Pendidikan nasional berfungsi mengembangkan kemampuan dan membentuk watak peradaban bangsa yang bermartabat dalam rangka mencerdaskan kehidupan bangsa, bertujuan untuk berkembangnya potensi peserta didik agar menjadi manusia yang beriman dan bertaqwa kepada Tuhan Yang Mahas Esa, berkakhlak mulia, sehat berilmu, cakap, kreatif, mandiri dan menjadi warga Negara yang demokratis serta bertanggung jawab (Departemen Agama, 2004).

Berkaitan dengan hal diatas, pendidikan memegang peranan penting dalam fungsinya sebagai penyiap peserta didik di masa yang akan datang sehingga dapat mengantisipasi keadaan masyarakat masa depan. Dengan pendidikan diharapkan dapat membentuk manusia Indonesia yang mampu menguasai ilmu pengetahuan dan perkembangan teknologi yang dibutuhkan untuk bersaing dengan negara-negara lain. Pendidikan juga menjadi tolak ukur dalam kemajuan peradaban sebuah bangsa se- 
hingga pendidikan merupakan hal yang mutlak yang harus dipenuhi dalam upaya meningkatkan taraf hidup bangsa Indonesia.

Jalur pendidikan dibedakan menjadi tiga, yaitu pendidikan formal, pendidikan non formal, dan pendidikan informal. Pendidikan formal diperoleh melalui lembaga pendidikan, yaitu sekolah yang merupakan pendidikan berjenjang dari pendidikan palng rendah sampai dengan pendidikan tertinggi. Jenjang pendidikan formal terdiri dari: (1) pendidikan dasar (SD, SMP), (2) pendidikan menengah (SMA, SMK), dan (3) pendidikan tinggi (Diploma, Sarjana). Pendidikan dasar adalah pendidikan yang lamanya sembilan tahun, diselenggarakan enam tahun di Sekolah Dasar dan tiga tahun di Sekolah Menengah Pertama. Pendidikan dasar bertujuan memberikan bekal kemampuan dasar kepada peserta didik untuk mengembangkan kemampuannya sebagai pribadi, anggota masyarakat, warga negara, dan anggota manusia serta mempersiapkan peserta didik untuk mengikuti pendidikan menengah.

Pendidikan menengah adalah pendidikan yang lamanya tiga tahun bertujuan untuk melanjutkan dan meluaskan pendidikan dasar serta mempersiapkan peserta didik menjadi anggota masyarakat yang memiliki kemampuan mengadakan hubungan timbal balik dengan lingkungan sosial, budaya, dan alam sekitar serta dapat mengembangkan kemampuan lebih lanjut dalam memasuki dunia kerja maupun pendidikan selanjutnya yaitu pendidikan tinggi. Jenjang selanjutnya adalah pendidikan tinggi dengan segala penyelenggaraannya. Pendidikan tinggi bertujuan untuk mempersiapkan peserta didik yang memiliki kemampuan akademis maupun kemampuan profesional yang dapat menerapkan, mengembangkan, dan menciptakan ilmu pengetahuan dan teknologi. Pada umumnya tingkat pendidikan yang berhasil dicapai oleh seseorang akan berpengaruh terhadap kehidupan bermasyarakat. Seseorang yang mempunyai latar 
belakang pendidikan yang tinggi menjadi lebih terhormat dan mempunyai kedudukan yang lebih tinggi dari pada seseorang yang mempunyai latar belakang pendidikan yang rendah. Melihat tuntutan dunia usaha kerja dewasa ini secara tidak langsung menuntut agar siswa harus meneruskan pendidikannya yang tidak hanya berhenti di pendidikan menengah saja tetapi dituntut melanjutkan sampai ke perguruan tinggi. Dengan memasuki perguruan tinggi, seseorang mahasiswa diharapkan dapat mempersiapkan diri untuk menyongsong kehidupannya dimasa mendatang untuk meningkatkan taraf hidup kearah yang lebih sempurna apalagi dalam era perdagangan bebas seperti sekarang ini.

SMA Pusaka 1 Jakarta yang terletak di Jalan Taruna Pahlawan Revolusi nomor 89 Duren Sawit yang mempunyai status terakreditasi A disamakan nomor 003859/2009. Berdasarkan observasi awal peneliti di SMA Pusaka 1 Jakarta yang melakukan wawancara bersama Ibu Hana dan Pak Ahmad selaku bagian kurikulum dan kesiswaan, menunjukan bahwa kondisi status sosial ekonomi orang tua siswa termasuk kedalam katagori menengah kebawah. Selain itu peneliti juga mendapatkan informasi bahwa pembayaran uang SPP sering terlambat, siswa baru melunasi uang SPP jika ujian akan dilaksanakan.

Dalam pendidikan, sarana dan prasarana sangat penting dibutuhkan. Sarana dan prasarana pendidikan dapat berguna untuk menunjang penyelenggara proses belajar mengajar, baik secara langsung maupun tidak langsung dalam suatu lembaga dalam rangka mencapai tujuan pendidikan. SMA Pusaka 1 Jakarta memiliki sarana dan prasarana meliputi ruang kelas, ruang perpustakaan, laboratorium IPA, ruang pimpinan, ruang guru, ruang tata usaha, tempat ibadah, ruang UKS, lapangan sekolah, tempat kantin dan tempat parkir kendaraan.

$\begin{array}{rrrr}\text { SMA } & \text { Pusaka } 1 & \text { Jakarta } \\ \text { berada di lokasi yang } & \text { kurang }\end{array}$


strategis karena jauh dari jangkauan kendaraan umum. Kondisi di luar sekolah SMA Pusaka 1 Jakarta juga sangat ramai karena sekolah tersebut terletak di tengah pemukiman warga yang padat penduduk. Selain itu peneliti juga melihat ada tempat pembuangan sementara (TPS) di samping parkiran sekolah dan ada kali dibelakang gedung sekolah. Hal ini tentu akan menganggu dalam proses belajar mengajar di SMA Pusaka 1 Jakarta.
Sebuah lembaga yang menyelenggarakan pendidikan, SMA Pusaka 1 Jakarta juga memperhatikan peserta didiknya untuk melanjutkan studi ke Perguruan Tinggi. Minat melanjutkan studi ke Perguruan Tinggi di SMA Pusaka 1 Jakarta tergolong masih rendah. Meskipun dalam setiap tahunnya selalu ada peningkatan jumlah siswa yang melanjutkan studi ke Perguruan tinggi. Adapun data siswa yang melanjutkan studi ke perguruan tinggi, yaitu:

Tabel 1: Jumlah Siswa yang Melanjutkan Studi ke Perguruan Tinggi di SMA Pusaka 1 Jakarta

\begin{tabular}{|c|c|c|c|c|}
\hline No & $\begin{array}{c}\text { Tahun } \\
\text { Ajaran }\end{array}$ & $\begin{array}{c}\text { Jumlah } \\
\text { Lulusan }\end{array}$ & $\begin{array}{c}\text { Jumlah Siswa yang } \\
\text { Melanjutkan Studi ke PT }\end{array}$ & $\begin{array}{c}\text { Persentase Siswa yang } \\
\text { Melanjutkan Studi ke PT }\end{array}$ \\
\hline 1 & 2012 & 129 & 51 & $39,5 \%$ \\
\hline 2 & 2013 & 123 & 56 & $45,5 \%$ \\
\hline 3 & 2014 & 72 & 34 & $47,2 \%$ \\
\hline
\end{tabular}

Berdasarkan tabel di atas, dapat diketahui bahwa sedikitnya lulusan SMA Pusaka 1 Jakarta yang melanjutkan studi keperguruan tinggi merupakan suatu indikasi rendahnya minat siswa untuk melanjutkan pendidikan ke jenjang yang lebih tinggi. Minat adalah suatu sikap yang mencenderungkan seseorang untuk melakukan sesuatu yang diinginkannya. Minat hal utama yang paling berperan dalam diri siswa yang ingin melanjutkan studi ke perguruan tinggi. Dengan minat seseorang akan lebih mampu melakukan 
sesuatu yang diminatinya disbanding dengan yang tidak diminatinya. Diawali dari adanya rasa ketertarikan dan kebutuhan untuk mengembangkan ilmu pengetahuan akan mendorong seseorang untuk melakukan suatu tindakan dan berpartisipasi di dalamnya. Begitu juga dengan melanjutkan studi ke perguruan tinggi, minat siswa melanjutkan studi ke perguruan tinggi akan mendorong mereka untuk berusaha memasuki perguruan tinggi karena mereka ingin mengembangkan ilmu dan pengetahuan.

Minat melanjutkan studi ke Perguruan Tinggi berarti keinginan seseorang untuk meneruskan pendidikannya ke jenjang yang lebih tinggi. Terdapat banyak faktor yang memperngaruhi minat siswa untuk melanjutkan studi ke Perguruan Tinggi antara lain adalah motivasi belajar, prestasi akademis, status sosial ekonomi orang tua, latar belakang pendidikan orang tua, sosialisasi perguruan tinggi di sekolah, dan pergaulan teman sebaya.
Motivasi belajar merupakan salah satu faktor internal yang mempengaruhi siswa terhadap minat melanjutkan studi ke perguruan tinggi. Motivasi belajar bisa berasal dari dalam individu itu sendiri maupun dari luar lingkugan individu. Siswa yag memiliki motivasi belajar yang tinggi akan lebih bersemangat untuk belajar. Namun hingga kini masih terdapat siswa yang memiliki motivasi belajar yang rendah. Hal ini terlihat dari rendahnya respon siswa terhadap kegiatan belajar mengajar di dalam kelas. Tidak antusiasnya siswa ini dapat terlihat terutama pada mata pelajaran yang siswa tersebut tidak suka. Selain itu, motivasi belajar siswa yang rendah dapat pula dilihat pada saat siswa mengerjakan tugas baik di sekolah maupun di rumah yang terlihat kurang bersungguhsungguh dan tidak tepat waktu.

Dalam proses belajar, motivasi sangat diperlukan, sebab seseorang yang tidak mempunyai motivasi dalam belajar, tak akan mungkin melakukan aktivitas belajar. Sehingga motivasi belajar 
memegang peranan yang penting dalam proses belajar. Berawal dari motivasi belajar yang rendah menyebabkam siswa tersebut tidak berminat untuk melanjutkan studi ke perguruan tinggi.

Keinginan peserta didik dari segi individu untuk mempunyai bekal di masa depan mengahadapi persaingan dunia kerja dan harapan untuk mempunyai kehidupan yang lebih baik akan selalu ada. Minat melanjutkan studi ke perguruan tinggi ditambah dengan prestasi yang baik merupakan peluang bagi individu untuk mempunyai kesempatan yang besar masuk Perguruan Tinggi. Oleh karena itu, prestasi belajar juga merupakan salah satu faktor internal yang mempengaruhi siswa dalam minat melanjutkan studi ke perguruan tinggi. Prestasi belajar merupakan salah satu tolak ukur keberhasilan seorang siswa. Bagi individu yang prestasi belajarnya belum maksimal akan mempunyai minat yang belum optimal untuk melanjutkan studi ke perguruan tinggi. Karena kenyataannya banyak ditemui siswa dengan prestasi belajar yang rendah memiliki rasa kurang percaya diri dan menimbulkan rasa tidak senang pada pendidikan dan mengurangi minatnya untuk mempertinggi jenjang pendidikannya.

Faktor yang tidak kalah penting adalah faktor eksternal seperti status sosial ekonomi orang tua yang merupakan salah satu mempengaruhi minat seseorang untuk melanjutkan studi ke perguruan tinggi. Masalah kondisi sosial ekonomi dan harapan masa depan anak dari orang tua pada akhirnya akan menimbulkan masalah bagi orang tua untuk menentukan alternatif pilihan terhadap kelanjutan sekolah anakanaknya. Pada kenyataannya siswa yang berasal dari keluarga dengan ekonomi yang cukup, mempunyai kesempatan yang lebih luas untuk mengembangkan kemampuannya melalui pendidikan tinggi. Hal ini jauh berbeda dengan siswa yang berasal dari keluarga yang memiliki sosial ekonomi yang rendah biasanya sadar akan 
ketidakmampuannya dan tidak memiliki minat untuk meneruskan pendidikannya ke jenjang yang lebih tinggi dan memilih untuk langsung mencari pekerjaan.

Tidak hanya status sosial ekonomi orang tua, tingkat pendidikan orang tua juga merupakan faktor eksternal yang mempengaruhi siswa dalam minatnya untuk melanjutkan studi ke perguruan tinggi. Tingkat pendidikan orang tua akan menentukan cara orang tua dalam membimbing dan mengarahkan anaknya dalam hal pendidikan. Tingkat pendidikan yaitu jenjang pendidikan yang telah ditempuh, baik formal maupun nonformal. Sikap yang terbentuk pada masing-masing individu pada setiap jenjang pendidikan formal akan berbeda-beda antara lulusan sekolah dasar, lulusan sekolah menengah pertama, lulusan sekolah menengah atas, lulusan perguruan tinggi. Tingkat pendidikan orang tua yang rendah akan cenderung sempit wawasannya terhadap pendidikan, lulus sekolah menengah sudah dirasa cukup. Sedangkan tingkat pendidikan orang tua yang tinggi akan lebih luas wawasannya terhadap pendidikan. Mereka akan mengarahkan dan membimbing anaknya untuk terus menambah ilmu sehingga anak tersebut mempunyai minat untuk melanjutkan studi, dalam hal ini adalah ke perguruan tinggi.

Faktor lain yang turut memberikan andil dalam mempengaruhi minat siswa untuk melanjutkan studinya ke perguruan tinggi adalah sosialisasi Perguruan Tinggi di sekolah. Kurang maksimalnya sosialisasi perguruan tinggi pada siswa di sekolah juga merupakan salah satu hal yang menyebabkan minat siswa melanjutkan studi ke perguruan tinggi belum optimal. Hal ini dikarenakan informasi tentang perguruan tinggi yang dibutuhkan oleh siswa kurang. Siswa hanya memperoleh sedikit informasi atau informasi tentang perguruan tinggi tidak lengkap. Sekolah hanya memberikan informasi tentang perguruan tinggi secara umum, tentang cara atau jalur masuk 
perguruan tinggi, gambaran secara garis besar suatu perguruan tinggi. Padahal siswa tidak hanya membutuhkan informasi tersebut tetapi juga pada detail informasi suatu perguruan tinggi. Ketika siswa tidak mengenal baik tentang perguruan tinggi itu maka siswa tersebut cenderung minatnya belum optimal untuk melanjutkan studi ke perguruan tinggi.

Selain faktor-faktor yang telah disebutkan di atas teman sebaya juga mempengaruhi seseorang minat siswa untuk melanjutkan studi ke Perguruan Tinggi. Remaja mempunyai kecenderungan membentuk kelompok dan melakukan kegiatan kelompok dengan teman-teman sebaya yang dekat dengannya. Pada kenyataannya, terdapat kecenderungan dimana kelompok teman sebaya yang kurang memiliki minat dalam hal pendidikan yang tinggi dan memlih untuk langsung bekerja setelah lulus akan membentuk pemikiran siswa menjadi kurang berminat dalam meneruskan studinya ke perguruan tinggi. Berdasarkan latar belakang dan permasalahan yang telah dikemukakan, penulis tertarik untuk mengadakan penelitian dengan judul "Pengaruh Status Sosial Ekonomi Orang Tua dan Motivasi Belajar terhadap Minat Melanjutkan Studi ke Perguruan Tinggi pada Siswa Kelas XI di SMA Pusaka 1 Jakarta.

\section{KAJIAN TEORI}

\section{Minat Melanjutkan Studi ke Perguruan Tinggi}

Minat sangat erat kaitannya dengan kehidupan diri pribadi manusia, kaitan itu adalah bahwa seseorang memiliki atau tidak memiliki minat terhadap sesuatu dapat ditentukan oleh keadaan dirinya sendiri. Penentuan ini biasanya terjadi karena banyak faktor, baik langsung yaitu dari dalam diri seseorang maupun dari luar. Keberadaan minat dalam diri seseorang biasanya dimanfaatkan sebagai usaha untuk pengembangan ilmu pengetahuannya.

Menurut Slameto, minat merupakan suatu rasa lebih suka 
dan rasa keterikatan pada suatu hal atau aktivitas, tanpa ada yang menyuruh, minat pada dasarnya adalah penerimaan akan suatu hubungan antara diri sendiri dengan sesuatu di luar dirinya. Minat dapat diekspesikan melalui pernyataan yang menunjukan bahwa seseorang lebih menyukai sesuatu hal daripada hal lainnya, dapat pula dimanfestasikan melalui partisipasi aktif dalam sesuatu aktifitas (Slameto, 2010:180).

Senada dengan Slameto, Djaali (2010:180) menyatakan bahwa minat dapat diekspresikan melalui pernyataan yang menunjukkan bahwa siswa lebih menyukai suatu hal dari pada hal lainnya, dapat pula dimanifestasikan melalui partisipasi dalam suatu aktivitas. Selanjutnya W.S Winkel (2004:30) sampai pada kesimpulan bahwa minat dmerupakan kecenderungan yang agak menetap, merasa tertarik pada bidang atau suatu hal tertentu dan merasa senang berkecimpung di bidang tersebut.
Berdasarkan beberapa pendapat para ahli yang telah dikemukakan dapat dikatakan minat merupakan aspek psikis yang dimiliki seseorang menimbulkan rasa suka atau senang terhadap sesuatu dan mampu mempengaruhi tindakan orang tersebut. Senada dengan pendapat di atas Abdul Hadis mengatakan "minat secara umum dapat diartikan sebagai rasa tertarik yang ditunjukan individu kepada suatu objek, baik objek benda hidup maupun benda tak hidup (Abdul Hadis, 2006:44).

Minat mempunyai hubungan erat dengan dorongan dalam dari individu yang kemudian menimbulkan ketertarikan untuk berpartisipasi atau terlibat pada suatu yang diminatinya. Seseorang yang berminat pada suatu objek maka akan cenderung memperhatikan perhatian yang besar terhadap objek tesebut. Perhatian pada objek tersebut dapat diwujudkan dengan rasa ingin tahu dan memperlajari objek tersebut. Selanjutnya Muhibbin Syah menegaskan bahwa minat berarti 
kecenderungan dan kegairahan yang tinggi atau keinginan yang besar terhadap sesuatu (Muhibin Syah, 2008:136). Menguatkan pendapat Muhibin, Sardiman AM menyatakan bahwa minat timbul tidak secara tiba-tiba atau spontan, melainkan timbul akibat partisipasi pengalaman, kebiasaan pada waktu belajar atau bekerja dan minat akan selalu terkait dengan soal kebutuhan atau keinginan (Sadirman, 2006:76). Sardiman menyatakan bahwa minat sebagai suatu kondisi yang terjadi apabila seseorang melihat ciri-ciri atau arti sementara situasi yang dihubungkan dengan keinginankeinginan atau kebutuhankebutuhannya sendiri. Singkatnya, apa yang dilihat seseorang sudah tentu akan membangkitkan minatnya sejauh apa yang dilihat itu mempunyai hubungan dengan kepentin ngannya sendiri. Daryanto (2009:53) sampai pada kesimpulan bahwa minat merupakan kecenderungan yang tetap untuk memperhatikan beberapa kegiatan yang diminati seseorang diperhatikan terus menerus yang disertai dengan rasa senang.

Dari beberapa pendapat tersebut dapat disimpulkan bahwa minat merupakan kecenderungan dari dalam individu diwujudkan dengan rasa suka atau senang, ketertarikan, dan memberikan perhatian terhadap hal yang diminatinya. Dalam hal pendidikan, kelanjutan karir seseorang siswa sangat bergantung dengan minatminat tiap siswa tersebut. Dalam hal ini, R. Ibrahim (2003:3) sampai pada kesimpulan bahwa setiap anak mempunyai minat dan kebutuhan sendiri-sendiri, anak yang akan bersekolah ke perguruan tinggi akan berbeda dengan anak yang bekerja seteah tamat sekolah menengah. Sesuatu yang menarik minat dan dibutuhkan anak akan menarik perhatiannya dan mereka akan bersungguh-sungguh dalam belajar.

Berdasarkan uraian tersebut dapat disintesiskan bahwa yang dimaksud dengan minat melanjutkan studi ke perguruan tinggi adalah motif, kecenderungan seseorang untuk meningkatkan taraf 
pendidikan yang lebih tinggi setelah lulus sekolah menengah melalui lembaga pendidikan formal yang lebih tinggi yaitu Perguruan Tinggi. Minat melanjutkan studi ke perguruan tinggi dapat diukur dengan indikator meliputi rasa suka atau senang, ketertarikan dan perhatian untuk meneruskan studi ke perguruan tinggi.

\section{Status Sosial Ekonomi}

Lingkungan

sosial merupakan lingkungan masyarakat yang didalamnya terdapat individu satu dengan individu lainnya. Dalam kehidupan bermasyarakat akan banyak ditemukan perbedaan yang membedakan seseorang dengan lainnya. Kemudian perbedaan tersebut akan membentuk suatu tingkatan yang tanpa disengaja akan menjadi pembeda di dalam masyarakat. Perbedaan tersebut dapat menggolongkan satu individu ke suatu tingkatan yang tanpa disengaja pula memasukan individu tersebut ke dalam suatu tingkatan tertentu. Tingkat tersebut bukanlah suatu hal dapat yang diminta ataupun ditolak karena perbedaan tersebut terjadi dengan sendirinya dan membentuk tingkatan dengan sendirinya.

Menurut Nasution (2004:22) status sosial merupakan kedudukan seseorang dalam suatu kelompok sosial. Kedudukan sosial (status sosial) adalah sehubungan dengan orang lain dalam arti lingkungan pergaulannya, prestisenya dan hakhak serta kewajibannya. Kedudukan sosial tersebut mempengaruhi kedudukan orang tersebut dalam kelompok sosial berbeda. Soekanto mendefinisikan "status atau kedudukan sebagai tempat atau posisi seseorang dalam suatu kelompok sosial sehubungan dengan orang-orang lainnya dalam suatu kelompok yang lebih besar lagi.

Selanjutnya Soleman B. Taneko (2000:131) sampai pada kesimpulan bahwa status sosial dapat dikonsepsikan sebagai posisi seseorang (kelompok) dalam suatu kelompok (kelompok yang lebih besar) sehubungan dengan orang lain dalam kelompoknya. Senada 
dengan Taneko, Idianto M (2005:39) juga memberikan definisi tentang status sosial, yaitu status sosial merupakan "kedudukan atau posisi sosial seseorang dalam masyarakat, mengikuti keseluruhan posisi sosial yang terdapat dalam suatu kelompok masyarakat, dari yang paling rendah hingga yang paling tinggi.

Berdasarkan uraian yang telah dipaparkan sebelumnya maka dapat disintesiskan status sosial ekonomi adalah posisi seseorang dalam suatu kelompok sosial masyarakat yang ditinjau dari segi ekonomi. Status sosial ekonomi dapat diukur melalui tingkat pendidikan, jenis pekerjaan, pendapatan dan kekayaan yang dimiliki.

\section{Motivasi Belajar}

Dalam proses belajar, motivasi sangat diperlukan, sebab seseorang yang tidak mempunyai motivasi dalam belajar, tak akan mungkin melakukan aktivitas belajar. Hal ini meupakan suatu pertanda bahwa sesuatu yang akan dikerjakan itu tidak menyentuh kebutuhannya. Sumadi Suryabrata (2011:70) menyatakan bahwa "motivasi adalah keadaan dalam pribadi orang yang mendorong individu untuk melakukan aktivitasaktivitas kondisi tertentu guna untuk mencapai suatu tujuan.

Sementara Sardiman A. M (2006:74), mengemukakan bahwa motivasi mengandung tiga elemen penting, yaitu: (1) motivasi itu mengawali terjadinya perubahan energi pada diri setiap individu manusia. Perkembangan motivasi akan membawa beberapa perubahan energi didalam sistem "neurophysiological" yang ada pada organisme manusia (walaupun motivasi itu muncul dari dalam diri manusia), penampakkannya akan menyangkut kegiatan fisik manusia;

(2) Motivasi ditandai dengan munculnya, rasa/ "feeling", afeksi seseorang. Dalam hal ini motivasi relevan dengan persoalanpersoalan kejiwaan, afeksi dan emosi yang dapat menentukan tingkah-laku manusia, dan (3) Motivasi akan dirangsang karena adanya tujuan. Jadi motivasi dalam 
hal ini sebenarnya respons dari suatu aksi, yakni tujuan. Motivasi memang muncul dari dalam diri manusia, tetapi kemunculannya karena terangsang/terdorong oleh adanya unsur lain, dalam hal ini adalah tujuan dan tujuan ini akan menyangkut soal kebutuhan.

Senada dengan Sardiman, menurut Bimo Walgito (2002:169) menyimpulkan bahwa motivasi mengandung 3 aspek yaitu: (1) keadaan tergolong dalam diri organism (a driving state), yaitu kesiapan bergerak karena kebutuhan misalnya kebutuhan jasmani, karena keadaan lingkungan, atau karena keadaan mental seperti berpikir dan ingatan; (2) Perilaku yang timbul dan terarah karena keadaan ini, dan (3) Goal atau tujuan yang di tuju oleh perilaku tersebut.

Berdasarkan beberapa pendapat sebagaimana telah diuraikan, dapat disimpulkan bahwa motivasi merupakan dorongan dari dalam individu yang memiliki kekuatan untuk merangsang dan mengarahkan manusia agar bertindak.
Merangsang berarti menumbuhkan kekuatan pada diri individu dan memimpin seseorang untuk bertindak dengan cara tertentu. Sedangkan mengarahkan berarti menyalurkan tingkah laku agar memiliki orientasi pada tujuan. Selanjutnya motivasi belajar merupakan dorongan yang ada pada diri siswa sebagai keseluruhan daya penggerak yang menimbulkan kegiatan belajar, disertai usaha-usaha dan cara-cara untuk meningkatkan pemahaman suatu mata pelajaran sehingga tujuan yang dikehendaki oleh subjek belajar itu dapat tercapai. Motivasi belajar ini dapat di ukur dengan indikator meliputi adanya hasrat dan keinginan untuk berhasil, adanya dorongan kebutuhan dalam belajar, adanya penghargaan dalam belajar, adanya lingkungan belajar yang kondusif.

\section{METODOLOGI PENELITIAN}

Penelitian ini dilakukan dengan menggunakan metode expost facto dengan pendekatan kausal yang menggunakan data 
primer (variabel eksogen dan variabel endogen). Penelitian expost facto data yang diperoleh adalah data hasil dari peristiwa yang sudah berlangsung, sehingga peneliti hanya mengungkapkan fakta berdasakan pengukuran gejala yang telah ada. Penelitian ini dilakukan untuk menggali informasi mengenai seberapa besar pengaruh sosial ekonomi orang tua dan motivasi belajar terhadap minat melanjutkan studi ke perguruan tinggi. Populasi dalam penelitian ini adalah seluruh siswa kelas XI SMA Pusaka 1 Jakarta. Analisis data dalam penelitian ini dilakukan dengan menggunakan analisis jalur (path analysis).

\section{HASIL DAN PEMBAHASAN}

Berdasarkan hasil penelitian path analysis, besarnya pengaruh status sosial ekonomi orang tua $\left(\mathrm{X}_{1}\right)$ yang secara langsung mempengaruhi minat melanjutkan studi ke perguruan tinggi ( $Y$ ) adalah $0,472^{2}=0,222$ atau $22,2 \%$. Artinya, status sosial ekonomi orang tua berkontribusi secara langsung terhadap minat melanjukan studi ke perguruan tinggi sebesar 22,2\%. Sedangkan pengaruh tidak langsung antara status sosial ekonomi orang tua terhadap minat melanjutkan studi ke perguruan tinggi yang dimoderatori oleh motivasi belajar berkontribusi sebesar 0,181 . Artinya status sosial ekonomi orang tua memperngaruhi minat melanjutkan studi ke perguruan tinggi dimoderatori oleh motivasi belajar sebesar $18,1 \%$. Berdasarkan uji persyaratan analisis, yaitu uji normalitas, variabel status sosial ekonomi orang tua berdistribusi normal karena siginifikan variabel lebih dari 0,05 dan dinyatakan.

Berdasarkan hasil perhitungan yang telah dilakukan, maka dapat diinterpretasikan bahwa status sosial ekonomi orang tua mempunyai pengaruh yang positif dan signifikan terhadap minat melanjutkan studi ke perguruan tinggi. Hasil penelitian ini sejalan dengan hasil penelitian sebelumnya yang dilakukan oleh Syafrina yang berjudul "Pengaruh Status Sosial 
Ekonomi Orang Tua terhadap Minat Melanjutkan Studi ke Perguruan Tinggi di SMA Sinar Husni Medan Helvetia" yang menemukan bahwa terdapat pengaruh positif dan signifikan antara Status Sosial Ekonomi Orang Tua terhadap Minat Melanjutkan Studi ke Perguruan Tinggi di SMA Sinar Husni Medan Helvetia. Hal ini dapat dilihat dari nilai koefisien determinasinya adalah sebesar $30,15 \%$. Nilai tersebut menunjukkan bahwa $30,15 \%$ minat melanjutkan studi ke perguruan tinggi ditentukan oleh status sosial ekonomi orang tua dan $69,85 \%$ dipengaruhi oleh faktor lain.

Keadaan sosial orang tua tidak terlepas dari keadaan ekonomi. Sebab untuk terpenuhinya kebutuhan keluarga diperlukan keadaan ekonomi yang memadai. Jika orang tua memiliki penghasilan yang tinggi maka kebutuhan keluarga lebih mudah terpenuhi namun jika orang tua memiliki penghasilan yang rendah kebutuhan keluarga juga lebih sulit terpenuhi khususnya mengenai pendidikan anak. Orang tua harus senantiasa meningkatkan keadaan ekonomi keluarga dan memperhatikan pendidikan anaknya. Ini dilakukan agar anak bersemangat dalam belajar dan berminat untuk melanjutkan studi sampai ke perguruan tinggi. Sebab banyak anak yang memiliki minat melanjutkan studi ke perguruan tinggi namun terkendala pada masalah ekonomi keluarga.

Berdasarkan hasil penelitian path analysis besarnya pengaruh motivasi belajar $\left(\mathrm{X}_{2}\right)$ yang secara langsung mempengaruhi minat melanjutkan studi ke perguruan tinggi $(Y)$ adalah $0,376^{2}=0,141$ atau $14,1 \%$. Artinya, motivasi belajar berkontribusi secara langsung terhadap minat melanjukan studi ke perguruan tinggi sebesar $14,1 \%$. Berdasarkan uji persyaratan analisis, yaitu uji normalitas, variabel motivasi belajar berdistribusi normal karena siginifikan variabel lebih dari 0,05 dan dinyatakan liniear, karena siginifikansi liniear variabel kurang dari 0,05. Hasil dari uji hipotesis, yaitu uji $\mathrm{t}$ untuk variabel motivasi belajar 
diketahui thitung $(4,629)>t_{\text {tabel }}(1,986)$ jadi Ho ditolak yang dapat disimpulkan bahwa motivasi belajar secara parsial berpengaruh terhadap minat melanjutkan studi ke perguruan tinggi.

Hasil penelitian ini didukung oleh penelitian sebelumnya yang dilakukan oleh Felicia Agustine yang berjudul Pengaruh Motivasi Belajar dan Metode Pembelajaran terhadap Minat Melanjutkan Studi ke Perguruan Tinggi pada SMK Bethel yang menemukan adanya pengaruh yang signifikan antara motivasi belajar terhadap minat melanjutkan studi ke perguruan tinggi sebesar $33,92 \%$ dan metode pembelajaran terhadap minat melanjutkan studi ke perguruan tinggi sebesar 24,22\%. Motivasi belajar merupakan faktor penting dalam kegiatan belajar karena motivasi belajar merupakan keadaan yang mendorong siswa untuk melakukan kegiatan belajar. Motivasi belajar berasal dari dalam ataupun luar siswa. Siswa yang memiliki motivasi belajar yang tinggi akan belajar terus menerus yang tidak hanya sampai lulus di sekolah menengah saja melainkan mempunyai niat untuk melanjutkan studinya ke perguruan tinggi.

Berdasarkan hasil uji hipotesis, yaitu uji $F$ dapat diketahui $F_{\text {hitung }}(52,893) F_{\text {tabel }}(3,10)$ sehingga dapat disimpulkan bahwa variabel bebas (status sosial ekonomi orang tua dan motivasi belajar) secara serentak berpengaruh terhadap minat melanjutkan studi ke perguruan tinggi. Selain itu, hasil dari uji koefisien determinasi diperoleh nilai $R$ square sebesar 0,535 , artinya variasi minat melanjutkan studi ke perguruan tinggi dapat dijelaskan oleh status sosial ekonomi orang tua dan motivasi belajar sebesar 53,5\%, sedangkan sisanya $\quad 46,5 \%$ ditentukan faktor lain yang tidak diteliti. Keeratan hubungan secara simultan antara variabel status sosial ekonomi orang tua, motivasi belajar dan minat melanjutkan studi ke perguruan tinggi adalah kuat yaitu sebesar 0,731 .

Hasil penelitian ini juga didukung oleh penelitian sebelumnya yang dilakukan oleh 
Prajanti Kusuma Ningrum yang berjudul Pengaruh Status Sosial Ekonomi Orang Tua dan Motivasi Belajar terhadap Minat Melanjutkan Studi ke Perguruan Tinggi pada Kelas XII di SMA Negeri 6 Surakarta tahun 2013 menemukan bahwa adanya pengaruh yang signifikan antara status sosial ekonomi orang tua terhadap minat melanjutkan studi ke perguruan tinggi sebesar $35,42 \%$, antara motivasi belajar terhadap minat melanjutkan studi ke perguruan tinggi sebesar 43,92\% dan antara status sosial ekonomi orang tua dan motivasi belajar secara bersama-sama terhadap minat melanjutkan studi ke perguruan tinggi sebesar 79,33\%. Hasil dari uji hipotesis, yaitu uji $t$ untuk variabel status sosial ekonomi orang tua diketahui thitung $(5,815)>$ $t_{\text {tabel }}(1,986)$ jadi dapat disimpulkan bahwa status sosial ekonomi orang tua secara parsial berpengaruh terhadap minat melanjutkan studi ke perguruan tinggi.

KESIMPULAN DAN SARAN
Berdasarkan hasil analisis data penelitian tentang Pengaruh Status Sosial Ekonomi Orang Tua dan Motivasi Belajar terhadap Minat Melanjutkan Studi ke Perguruan Tinggi pada Kelas XI di SMA Pusaka 1 Jakarta maka peneliti dapat mengambil kesimpulan bahwa: (1) Ada pengaruh langsung antara status sosial ekonomi orang tua terhadap minat melanjutkan studi ke perguruan tinggi di SMA Pusaka 1 Jakarta sebesar 22,2\%. Artinya, status sosial ekonomi orang tua berkontribusi secara langsung terhadap minat melanjukan studi ke perguruan tinggi sebesar $22,2 \%$; (2) Ada pengaruh langsung antara motivasi belajar terhadap minat melanjutkan studi ke perguruan tinggi di SMA Pusaka 1 Jakarta sebesar 14,1\%. Artinya, motivasi belajar berkontribusi secara langsung terhadap minat melanjukan studi ke perguruan tinggi sebesar $14,1 \%$; (3) Sedangkan pengaruh tidak langsung antara status sosial ekonomi orang tua terhadap minat melanjutkan studi ke perguruan 
tinggi yang dimoderatori oleh motivasi belajar berkontribusi sebesar 0,181 . Artinya status sosial ekonomi orang tua mempengaruhi minat melanjutkan studi ke perguruan tinggi dimoderatori oleh motivasi belajar sebesar $18,1 \%$; (4) Total pengaruh langsung dan tidak langsung status sosial ekonomi orang tua terhadap minat melanjutkan studi ke perguruan tinggi sebesar 0,653 atau 65,3\%; (5) Pengaruh status sosial ekonomi orang tua dan motivasi belajar secara bersama-sama terhadap minat melanjutkan studi ke perguruan tinggi dapat dilihat dari $R$ square sebesar 0,535 menunjukkan variasi minat melanjutkan studi ke perguruan tinggi dapat dijelaskan oleh status sosial ekonomi orang tua dan motivasi belajar sebesar $53,5 \%$, sedangkan sisanya $46,5 \%$ ditentukan faktor lain yang tidak diteliti. Keeratan hubungan secara simultan antara variabel status sosial ekonomi orang tua, motivasi belajar dan minat melanjutkan studi ke perguruan tinggi adalah kuat yaitu sebesar 0,731 .
Berdasarkan kesimpulan yang dikemukakan di atas, saransaran yang kiranya dapat diberikan peneliti adalah: (1) Sebaiknya orang tua selalu memantau dan membimbing anaknya dalam belajar. Orang tua juga diharapkan dapat mengoptimalkan pendapatannya dengan bekerja lebih giat sehingga dapat lebih memperhatikan kebutuhan anaknya seperti memberikan fasilitas, sarana prasarana belajar dan mempersiapkan tabungan khusus untuk pendidikan anak. Dengan adanya dukungan dari orang tua dapat menumbuhkan minat siswa untuk melanjutkan studinya ke perguruan tinggi; (2) Siswa seharusnya selalu mempunyai motivasi belajar yang tinggi dengan cara tekun dalam belajar, ulet menghadapi kesulitan belajar dan tidak melihat latar belakang status sosial ekonomi orang tuanya yang tinggi ataupun rendah untuk menurunkan semangat belajarnya, karena bagi siswa yang memiliki status sosial ekonomi orang tua yang tergolong rendah masih 
banyak cara untuk melanjutkan studinya ke perguruan tinggi seperti program beasiswa; (3) Guru diharapkan untuk lebih mengoptimalkan kegiatan belajar mengajar di kelas dengan menggunakan metode pembelajaran yang beragam guna meningatkan motivasi belajar siswa tersebut. Guru juga harus memberikan arahan atau sosialisasi yang memadai mengenai perguruan tinggi sehingga akan menumbuhkan minat siswa untuk belajar tidak hanya sampai lulus di sekolah menengah saja, dan (4) Pihak sekolah hendaknya menjalin hubungan yang baik dengan perguruan-perguruan tinggi agar dapat memfasilitasi setiap siswanya untuk mencari berbagai informasi tentang perguruan tinggi, dan bekerja sama dengan perguruan tinggi tersebut agar menyediakan program beasiswa bagi lulusan siswa yang kurang mampu tapi memiliki semangat belajar untuk dapat terus melanjutkan studinya hingga ke perguruan tinggi.
Adi, Rianto. (2004). Metodologi Penelitian Sosial dan Hukum. Jakarta: Granit.

A.M, Sadirman. (2006). Interaksi dan Motivasi Belajar Mengajar. Bandung: PT Remaja Rosdakarya, 2006.

Arikunto, Suharsimi. (2007). Manajemen Penelitian. Jakarta: Rineka Cipta. .(2012).

Dasardasar Evaluasi Pendidikan. Jakarta: Bumi Aksara.

Aunurrahman. (2011). Belajar dan Pembelajaran. Bandung: Alfabeta.

Bahri, Djamarah, Syaiful. (2008). Psikologi Belajar. Jakarta: PT Rineka Cipta.

Bimo Walgito. (2002)

B. Tenako, Soleman. (2000). Struktur dan Proses Sosial, Suatu Pengantar Sosiologi Pembangunan. Jakarta: PT Raja Grafindo Persada.

Buchori. (1985).

Psikologi Pendidikan. Jakarta: Rineka Cipta.

Daryanto. (2009). Panduan Proses Pembelajaran Kreatif \& Inovatif. Jakarta: Publisher.

Djaali.(2010). Psikologi Pendidikan. Jakarta: Bumi Aksara.

Hadi, Soedomo.(2008). Pendidikan suatu Pengantar. Surakarta: UNS Press.

Hadis, Abdul. (2006). Psikologi dalam Pendidikan. Bandung: Alfabeta.

Hamalik, Oemar. (2005). Proses Belajar Mengajar. Jakarta: PT Bina Aksara.

\section{DAFTAR PUSTAKA}


Ibrahim. (2003). Perencanaan Pengajaran. Jakarta: Rineka Cipta.

Ihsan, Fuad. (2003). Dasar-dasar Kependidikan. Jakarta: Rineka Cipta.

M, Idianto. (2005). Sosiologi untuk SMA kelas XI. Jakarta: Erlangga.

Nasution. (2004). Sosiologi Pendidikan. Bandung: Jemmars.

Robert, Slavin. (2008). Psikologi Pendidikan Teori dan Praktik. Jakarta: Indeks.

Slameto. (2010). Belajar dan FaktorFaktor yang Mempengaruhinya. Jakarta: PT. Rineka Cipta.
Soekanto, Soerjono. (2004). Sosiologi Suatu Pengantar. Jakarta: CV Rajawali Pers.

S. Roucek Joseph and L. Warren Roland (2002). Sociology an Introduction, Terjemahan Sahat Sinamora, Pengantar Sosiologi. Jakarta: PT Bina Aksara.

Suryabrata, Sumadi. (2011). Psikologi Pendidikan. Jakarta: PT. Rajawali.

Syah, Muhibin. (2008). Psikologi Pendidikan Dengan Pendekatan Baru. Bandung: PT. Remaja Rosdakarya.

Winkel, WS. (2004). Psikologi Pengajaran. Jakarta: Media Abadi. 